\title{
A Comparative Study on the Alteration of Industrial Structure in Chinese and American Urbanizations
}

\author{
Linxiu Huang1,2 \\ ${ }^{1}$ College of Economics and Management, Southwest University, Chongqing, China \\ ${ }^{2}$ Regional Economics and Application Lab, University of Illinois at Urbana-Champaign, Urbana-Champaign, US \\ Email: huanglx@swu.edu.cn
}

Received 16 May 2014; revised 18 June 2014; accepted 15 July 2014

Copyright (C) 2014 by author and Scientific Research Publishing Inc. This work is licensed under the Creative Commons Attribution International License (CC BY). http://creativecommons.org/licenses/by/4.0/ (c) (i) Open Access

\begin{abstract}
Urbanization is internally related to economic growth and industrial structure. Whether China may fall into the mid-income trap, to some extent, depends on the benign interaction between the advancement of urbanization and the upgrade of industrial structure. The present paper, by a comparative analysis of relevant issues in China and the United States, is intended to find out the features of interaction in the experiences of the United States so as to get inspirations in policy making in China.
\end{abstract}

\section{Keywords}

\section{Urbanization, Industrial Structure, Alteration}

\section{Introduction}

The concept of highly developing economic being, which refers to a economic being with a 7\% of GDP increase rate in 25 years or more, was put forth in 2008 in a report by Increase \& Development Committee of world Bank. By means of generalizing the records of economic development in more than 100 countries or regions after World War II, Michael Spence, chief presenter and Nobel Prize winner for economics, pointed out that high development had been found in only 13 economic beings, namely, Botswana, Brazil, Chinese Mainland, Hong Kong, Taiwan, Indonesia, South Korea, Malaysia, Malta, Oman, Singapore, Thailand and Japan, of which China saw the most rapid economic development by the largest margin. In this period, the concept of Middle Income Trap was put forth in 2006 Report on Economic Development of East Asia by World Bank. Middle Income Trap means that, when the newly booming countries have broken away from the Middle Income Trap, namely, 1000 
US dollars of GDP per capita, they will rush toward the "flight stage" of 1000 - 3000 US dollars, and that the countries will be apt to be trapped in a standstill of economic development when they come up to 3000 US dollars of GDP per capita. For example, Brazil, Argentina, Mexico, Chile and Malaysia, etc., became mid-income countries in 1970s, but up to now, these countries are still in the developing stage with their per capita GDP of 3000 - 5000 US dollars. It is universally acknowledged that the reason why the countries got trapped lies in the fact that they failed to realize the transformation of economic development and upgrade of industrial structure in a smooth way.

\section{Discussing Questions}

In 2007, China's per capita GDP came up to 3000 US dollars for the first time. After that an obvious slowdown was seen in China's economic development.

Table 1 refers to china's GDP increasing rates of the years since China's reform and open up campaign. By means of $\mathrm{H}-\mathrm{P}$ wave filtering, the increasing speed of GDP tendency value and the average value have been obtained as follows.

Since the years of reform and opening up, China's economic increase could be divided into two cycles, namely the cycle of from 1979 to 1999, and the other from 2000 to now. 1995, as a demarcation line, saw a dramatic alteration in supply-require relationship of China's commercial market, in that the previous undersupplying trend turned to over-supplying trend. The increasing speed declined for the first time. After 2007, when the per capita GDP surpassed 3000 US dollars, its GDP had a declining trend for the second time (Figure 1 and Figure 2).

Will the declination of China's economy be caused by the fact that it was caught in Middle Income Trap?

The economists vary in their opinions on whether China's economy will be caught in Middle Income Trap when China intends to maintain its rapid increase. China's economy is generally judged on favorable aspects by various authoritative figures, such as Stephen Rocky, researcher of Jackson Global Affairs Institute, Harvard University, Rajiv Biswas, chief economist of Asia-Pacific Section of Global Insight, an institute for economic analysis \& inquiry in USA, Huang Yuchuan, an experienced researcher in Carnegie Endowment for International Peace, USA, Nicolas Radi, senior researcher of Pedersen Institute for International Economics, USA, Cuodi, vice secretary general of Thailand Investment Promotion Committee, and Liang Guoyong, a official of Group

Table 1. Increasing rate of China’s GDP (1980-2012) Unit: 100\%.

\begin{tabular}{cc}
\hline year & Increasing rate \\
\hline $1980-1999$ & 7.85 .29 .110 .915 .213 .58 .811 .611 .34 .13 .89 .214 .213 .512 .610 .59 .68 .87 .87 .1 \\
$2000-2012$ & 8.07 .58 .39 .510 .110 .410 .711 .49 .69 .29 .210 .39 .27 .8 \\
\hline
\end{tabular}

Source of data: National Statistic Bureau of China.

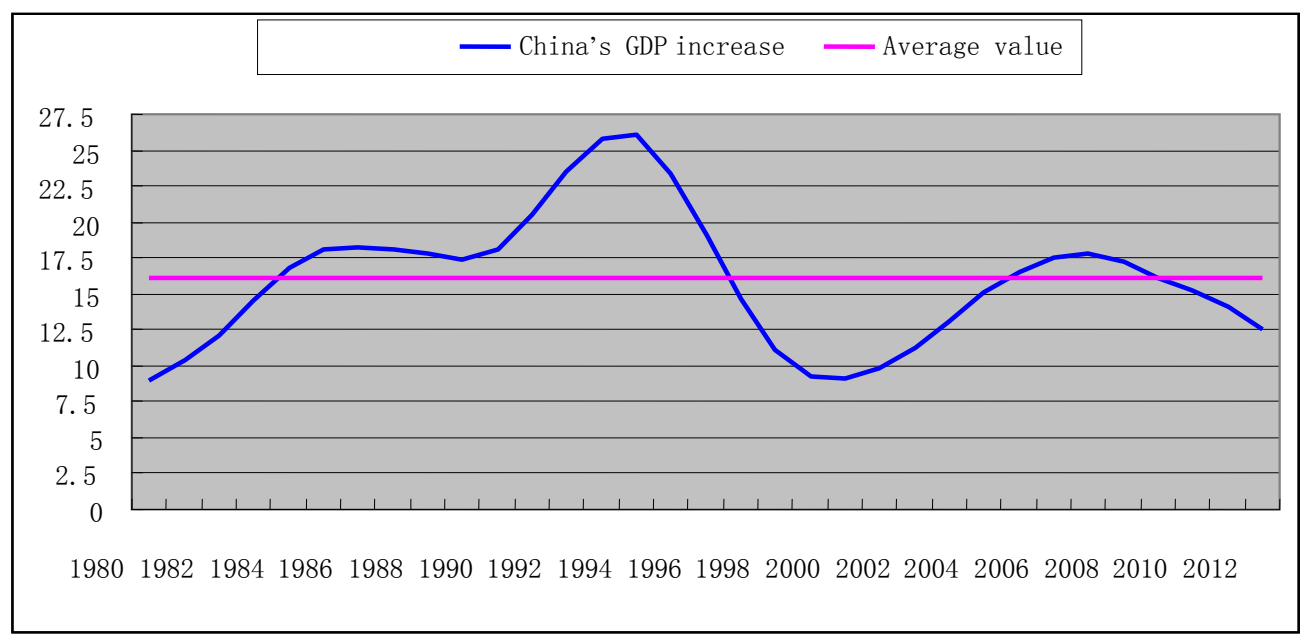

Figure 1. Average value of the whole time span: from 1980 to now. 


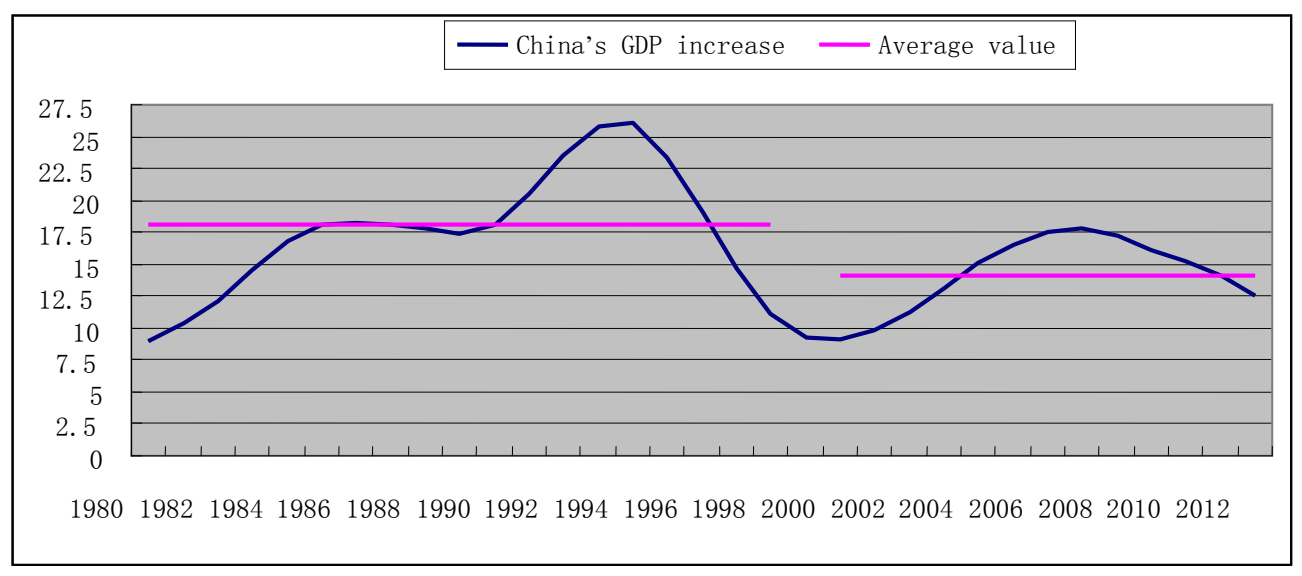

Figure 2. Average value at different time span: 1980-1999; 1999-now. Source of data: National Statistic Bureau of China.

Investment and Enterprise Division of the United China World Trade Center. All of them hold that China's slowdown in economic development lies in the outer factors and cycle ones. Nowadays, the important mid-term structural reform is on the move. Although China is slack in export requirement in that iron and steel and other key industries encountered production surplus, yet the consumers still keep confident to them. The economic competitiveness will be improved and sustainable development of China's economy promoted by means of financial reform, constraint of surplus production, promotion of civil consumption, and decrease of the dependency on export.

Tomas Rawski, a professor of economics in the University of Pittsburgh, USA, Lang Xianping, Stoudemire, chief editor of an American journal titled China's Economy, and Zhang Jiadun, etc., have drawn a conclusion that a hard landing of China's economy will result from various elements such as China's superbly big M2, economic recession, bonus ending of lowly-paid labors, bubble housing market, surplus investment, surplus production, poverty at old ages, and the over-expanded gap between the rich and the young, etc. Of the authoritative figures, the most influential one is Tomas Rawski, who, in 2000, had his article titled What's Happening to China's GDP Statistics published. By studying the statistical economic materials given by various provinces or municipalities in China, he found that the data in such materials failed to conform to those published by National Bureau of Statistics of China. Thus, he put forth his suspicion to China's statistic data. His article was reprinted in various key western journals or newspapers, such as USA's News Week and Business Week, Britain's The Financial Times and The Economist, before a conclusion was drawn that "China's economic development is but an illusion."

It is well-known that severe global economic inflation broke out during the very period. Hence, it's difficult to get a sound judgment unless there is a further study on it.

\section{Literature Review}

The industrial development and arrangement has been closely related to geographic or spatial elements since location theory came into being. Other latter theories, such as the growth pole theory, center periphery theory, and industrial cluster theory, etc., are related further to the statement that the change of industrial spatial arrangement will result in agglomeration and expansion of the inhabitant settlement. This, hereby, will promote urbanization and even will make city belt come into being. Despite this notion of urbanization being a transitory phenomenon, there isn't actually have a good conceptual model of the dynamic transitory process. The research of urbanization per se is static and empirical. The traditional versions focus on the question of urban "bias", or the effect of government policies on the urban-rural divide, or the efficient rural-urban allocation of population at a point in time [1]. The notion of dual sector model given by Lewis W. A., Nobel Prize winner for economics in 1979, is of great significance. With this model, he revealed the academic process of the shift of rural population toward the urban population driven by the evolution of industrial structure. On the basis of that there emerged another two models, namely, Rannis-Fei Model [2] and Jorgenson Model [3]. Todaro Model [4] shows the fact that the model research has attend to the reality of unemployment, which is popular in the developing countries. The fi- 
nal and most complex version of the models are the Kelley and Williamson (1998) and the Becker, Mills, and Williamson (1984), which are CGE (Computable General Equilibrium) models which introduce dynamic elements. Theory of stages of economic growth, developed by Walt Whitman Rostow [5], an American economist, divides a country's process of economy development into 6 stages, and gives a exploration of the alteration of industrial structure and the requirement for the urbanization standard on different stages. H. Chenery and M. Syrquin quantified Rostow's research. Their H. Chenery and M. Syrquin Model [6]) is a labor allocation model with which to reveal the quantitative relationship between the productive structure and employment structure of certain firms. It was established on the basis of reverted analysis of the related data from 1950 to 1970 of 101 countries, aiming mainly at realizing the coordination between the economic structure and employment structure. According to their model [7], an industrial deviation = the proportion of employment - the proportion of production; the general deviation = the total sum of absolute deviations of each industrial structure. When the model was reformed, it was popularly used in the studies on the interaction between the alteration of industrial structure and urbanization as an important evidence to judge whether the alteration of urbanization goes coordinately with that of industrial structure. After that, a lot of documents will be used to discuss under-urbanization and over-urbanization.

In an average balanced model on neo-classical urbanization established by Yang Xiaokai and Rice in 1994, it is demonstrated that the origin of cities and the urban-rural separation result from the evolution of labor divisions. In a book titled Urban Economy by Jane Jacobs (2007), the promoting function of industrial development to urbanization has been demonstrated from the perspectives of history and economy.

Generally speaking, the evolution of industrial structure results in urbanization and industrialization of economy, and the shift of industrial spatial arrangement in agglomeration and expansion of the inhabitant settlement. It actually reveals the process of urbanization.

\section{Empirical Analysis of Urbanization and Alteration of Industrial Structure in China and USA}

\subsection{Method and Data Resource}

By means of comparative and empirical studies, and with a lot of statistic materials, a comparative analysis has been conducted on American urbanization and alteration of industrial structure since $20^{\text {th }}$ century and those of China since 1980. The analysis lies on the standard of GDP, the standard of urbanization and the alteration of industrial structure. In 1900, USA surpassed Britain for the first time, with its per capita GDP of 206.00 US dollars. Its per capita GDP came up to 5066.00 dollars in 1959, which equals to that of China nowadays. In 1970, the per capita GDP came up to 10383.00 in USA. During this period, USA leaped to the stage of a high-income country (according to the criteria of World Bank, the per capita GDP of the high-income country is 10000 US dollars). 1900 saw $40 \%$ of urbanization. Up to 1970 , the urbanizing level came up to $75 \%$, and urbanization almost realized. This period saw that USA finished the shift of industrial structure in that its service industry instead of manufactory industry began to dominate.

1979 saw a rapid economic development in china, along with the implementation of the reform and opening-up policies. 2011 saw China attended for the first time to 5432 US dollars of per capita GDP. In this period, China's urbanization developed rapidly, with $19.4 \%$ up to $47 \%$ in 2010 . In this period, the industrial structure changed initially from the second industry to the third industry, but the manufacturing industry still prevailed. By comparing and analyzing urbanization and alteration of economic structure of China and USA, some valuable lesson or significance can be drawn. It will do good to China when it changes from a mid-income country to a high-income one. The pursuit for the difference in industrial structure of the two countries will be helpful in judging the right road and its potentialities.

\subsection{The Urbanization, Economic Increase and Industrial Alteration of USA ${ }^{1}$}

\subsubsection{The Population Increase during US Urbanization since 1900}

The $20^{\text {th }}$ century saw the rapid development of Urbanization in USA. In 1900 , it had $40 \%$ of its urbanization,

\footnotetext{
${ }^{1}$ Data resource on urbanization and industrial structure of USA comes from The Cambridge economic history of the United States of America, America Demographic History Chart Book: 1970 to 2010 (Campbell Gibson, www.demographicchartbook.com), and Guotai Junan Stock Exchange. The data on mobile industry of China are from Statistic Yearbook of Industrial Economy of China, Yearbook of Mobile Industry of China, and the information internet of the Association of Mobile Industry: http://www.auto-stats.org.cn/default.asp
} 
and in 1975, 75\%, almost up to completion of urbanization. Each stage of its urbanization possesses certain feature: In the first stage (1900-1930), it mainly featured by the fact that the populations were moving to the big cities and the boundaries of big cities were expanded. This stage saw rapid increase of urban population, without clear tendency of suburb development. During the period from 1930 to 1940, because of the influence of the Great Depression and World War II, the urbanization almost came to a stop. In the second stage (1940-1970), the urbanization began to develop in a high speed, with the suburbanization promoted (1945-1970) (Figure 3, Table 2). The third stage (1970 to now) saw a slow increase of urbanization and suburbanization in USA. The American suburbanization can be divided into the following four stages: 1) the initial stage, that is, the rich moved to the suburban area at first; 2) the forming stage, that is, lots of mid-classed people began moving and settling down in the new developing zone of the suburban area, but they still work, do shopping and entertain themselves in downtown; 3) the developing stage, that is, the suburbanization of inhabitant area and industry; 4) the developed stage, that is, the suburban area has improved from its inhabitant function to its multi-functional working center. The suburban population is the indispensable part of urban population, and the emergence of suburbanization results in the formation of multi-centered urban structure and the development of large-scale city belt [8].

In 2010, only 300,000 or more inhabitants lived in each American city with coverage of 300 square kilometers, with 10,000 inhabitants per square kilometer. In China, however, every square kilometer is occupied with 10,000 inhabitants, which is 10 times that of the cities in USA. According to a survey made by US Real Estate Agent Association in 2011, about $80 \%$ of the adult people favor to live in independent houses, only $8 \%$ of the people like living flats. So to speak, in suburban area of American cities, three fourths of inhabitants live in such houses. Or in other words, $90 \%$ of the American inhabitants increasing from 2000 to 2012 live in the suburban area.

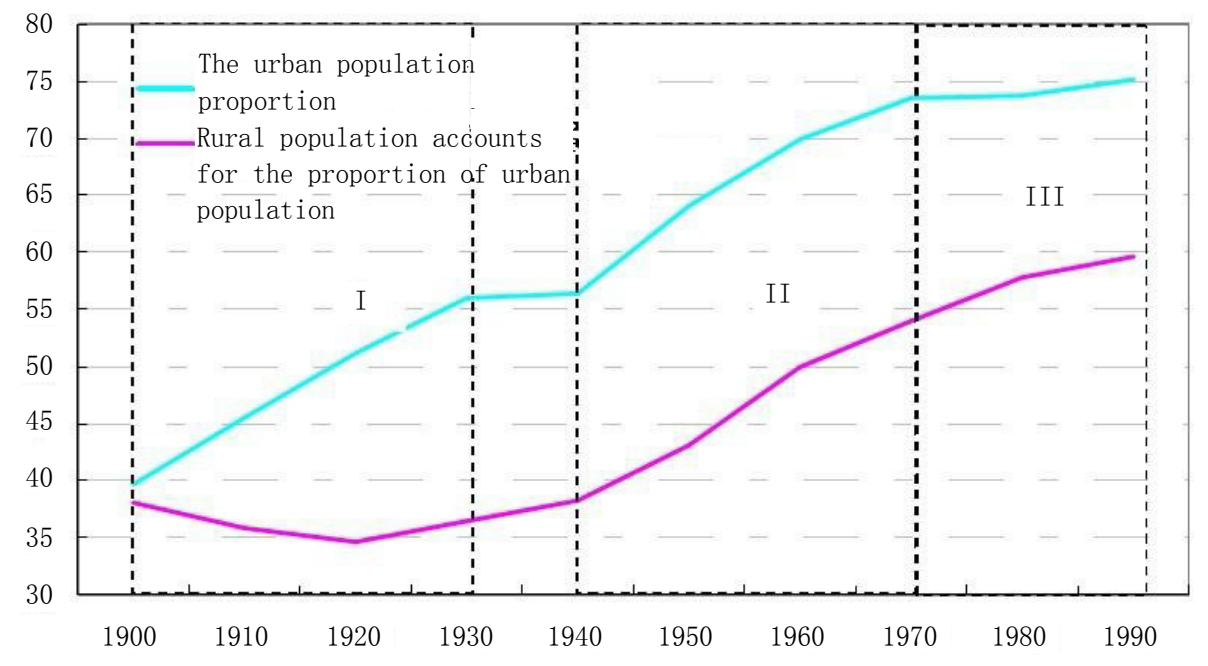

Figure 3. Proportions of urban-rural population in USA Unit: \%.

Table 2. Average population density in USA (1940-1990).

\begin{tabular}{ccccc}
\hline Decade & Amount of Cities & Population & Coverage & Density \\
\hline 1940 & 412 & 128051 & 19.2 & 6742 \\
1950 & 481 & 128811 & 19.5 & 6536 \\
1960 & 673 & 112400 & 22.8 & 5340 \\
1970 & 835 & 104785 & 28.5 & 4673 \\
1980 & 944 & 97756 & 32.8 & 3998 \\
1990 & 1063 & 98108 & 34.9 & 3783 \\
\hline
\end{tabular}

Data source: Sukko Kim \& Robert A. Margo. Historical Perspective on U.S. Geography. Handbook of Regional and Urban Economics, 2003, volume 4 August. 


\subsubsection{The Geographic Distribution of American Urbanization}

The urbanization in USA shows a process of going from unbalanced condition to balanced condition among various districts. In 1900, the urban population in northeast region, the most developed part in USA, occupies $66.1 \%$ of the whole population, while there was only $18 \%$ of population in the backward south region of USA. From 1945 up to now, there is a tendency of gradual contraction in population distribution. Since 1980, the urbanization became stable in various regions, and each section of USA saw a 70\% - 80\% basic distribution of urbanization, only the western area came up to $86.3 \%$ of urbanizing distribution. Thus a balanced development has finally obtained.

According to Figure 4, it can be seen that the contraction of US population distribution goes agreeably with its increased process of urbanization.

\subsubsection{Alteration of Industrial Structure in Process of US Urbanization}

Since 1940, the increased urbanization in USA was accompanied by the trend of suburbanization. In this period, the manufactory industry of USA expanded from the concentrating area to the backward areas. In 1950, in the first round of global great industrial shift, USA moved its traditional manufactory industry such as steel and textile industries to other countries such as Japan and Western Germany, and the new tech-intense industries, such as semi-conductor, communication, and computer, etc., were developed at home. In this round of urbanization, industry was shifted spatially, and on the other hand, there appeared sustainable adjustment in the industrial structure (Figure 5).

First, the proportion of GDP in agriculture and manufactory industry kept declining. In 1910, the American agriculture occupied 31.1\% of GDP, down to 18.3\% in 1940. In 1970 when urbanization was finished, its agricultural GDP declined to 3\%, and it kept below 3\% later. Its manufactory industry occupied $23.3 \%$ of GDP in 1940 , and in 1960, it came to the peak of $28.3 \%$. After that, it kept declining. In 1970, its employment proportion was surpassed for the first time by the serve industry. Nowadays, it keeps at $15 \%$.

Second, the proportion of GDP in service industry, financial and trade industry kept increasing. In 1940, the GDP of service industry and of financial and trade industry were $20.6 \%$ and $21.5 \%$ respectively. They kept going up after that. In 1970, they were respectively $28.5 \%$ and $28.6 \%$. Nowadays, GDP of service industry and financial and trade are still on the rise. At present, USA is the biggest import-export country of service industry with favored business. Its service industry is very advanced, and it kept a very important position in the national economy. Of this, the mass sale and detailed sale occupied an important part in financial industry and trade, but the development of business service and Finance, insurance, and real estate greatly surpassed the whole sake trade and Retail trade (1940-1990 were respectively 210.5\%, 115.6\%, and 29.2\%). In the service business, professional service and entertainment developed the fastest. Generally speaking, modern service dominates the American service industry, and meanwhile, the productive service industry keeps increasing in proportion, which makes it possible to make its structure keep improving and upgrading.

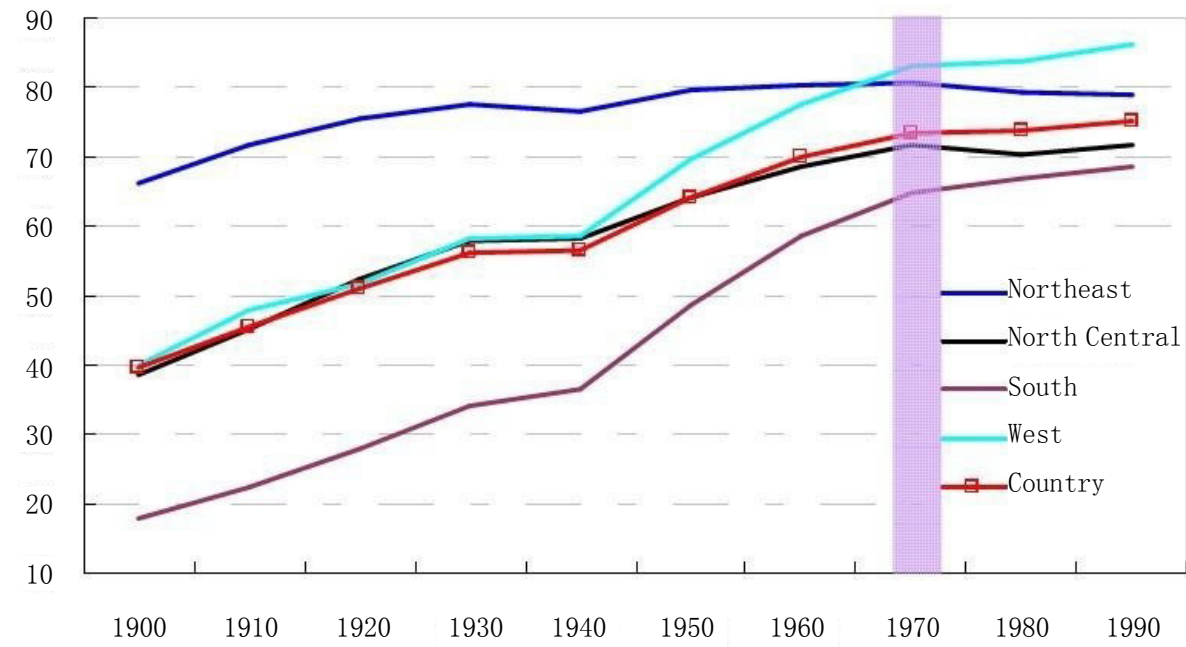

Figure 4. Proportion of urban population in various section of USA Unit: \%. 


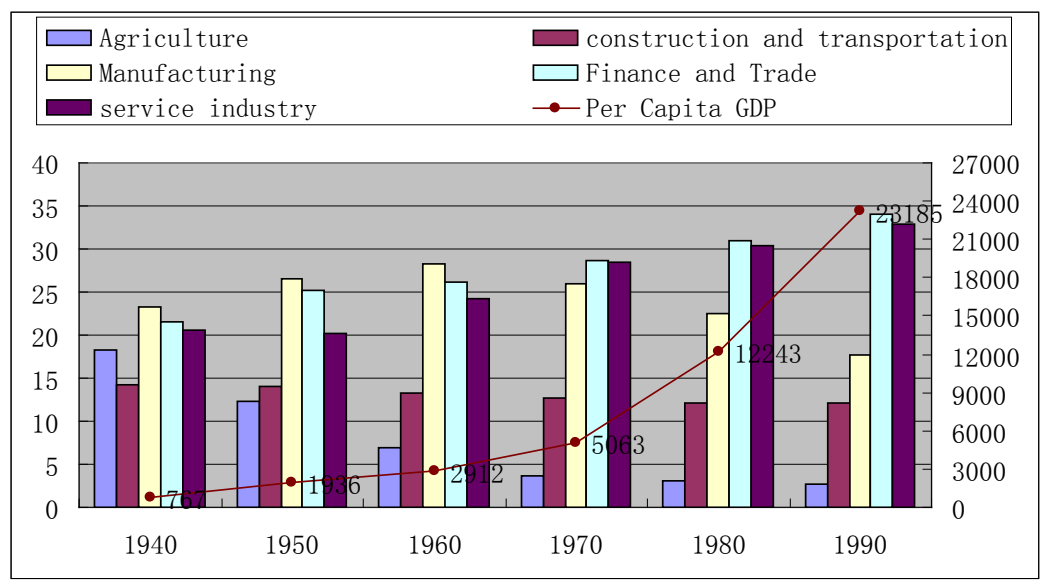

Figure 5. Alteration of GDP proportion of US industries \& per capita GDP (Left side unit: \%, right side unit: US dollar).

Additionally, the proportion of GDP in building industry and transportation industry keeps stable. In consideration of the fact that communications and transportation were put together in statistics in U.S. before 2000, its actual developing speed should be in a tendency of declination.

\subsubsection{Two Special Cases}

1) The American manufactory industry has been kept declining during the process of urbanization, but the automobile industry proves to be exceptive. In 1893 when Henry Fort invented the first gasoline-engined car, USA began driving into the Autmobile Time. From the early 20th century to now, USA's automobile industry has a history of more than 100 years, which makes USA a true empire of automobile and a superpower of industry. Before 1970, USA produced $50 \%$ of automobiles of the world total, peaking at $96.5 \%$ in 1916 . The annual increase of auto production always surpasses the average increase of GDP of USA, with 3\% of direct contribution to American national economy. This made it the key industry in USA. Since 1970s, along with the booming development of automobile industry in Japan and Europe, USA has lost its absolute domination in this realm.

USA is always listed as No. 1 in the world in automobile sale. In 1916, for the first time, it covered 1,000,000 cars, and more than 2,000,000 in 1920. In 1929, when USA was stricken in the Great Depression, it was more than 5,000,000. And 1965 saw the sale amount of 10,000,000 cars. In the following years, the amount is more or less 10,000,000. Of this, the private automobile sale grows the fastest. (Liu Bing, 2009).

Figure 6 reflects the data of the registered cars in USA in previous 100 years and that in China in previous 20 years. It can be seen that the US automobile industry serves as an important promotion to USA's suburbanization. The 1900-2008 China is equal to the USA in pre-World War II period. What is more, China's automobile only covers less than $1.5 \%$ in its contribution to the national economy, which is by far lower that USA before 1970s. Hence, automobile industry will have a long way to go before it becomes the key industry of China's national economy.

2) An obvious association between USA's economic development and its urbanization.

3) With 1980 as the boundary line, there appears an obvious difference in the increasing trace. The previous economic increase results from the promotion of urbanization, while the latter, from the development of internet technology and the increase of consumption [9] [10]. So to speak, USA's economic increase after the urbanization relies more upon the technological innovation. The enhancement of Economic development promoted by urbanization is maintained at a fairy high level, but it shows a declination at the completion of urbanization (Figure 7).

\subsection{China's Urbanization, Economic Increase and Industrial Alteration since 1980}

\subsubsection{China's Population Increase during Urbanization}

From 1949 to 1979, because of the urban citizenship system, China's urbanization was strictly controlled, which made the urban population increased very slowly. The proportion of world urban population goes from $28 \%$ up 


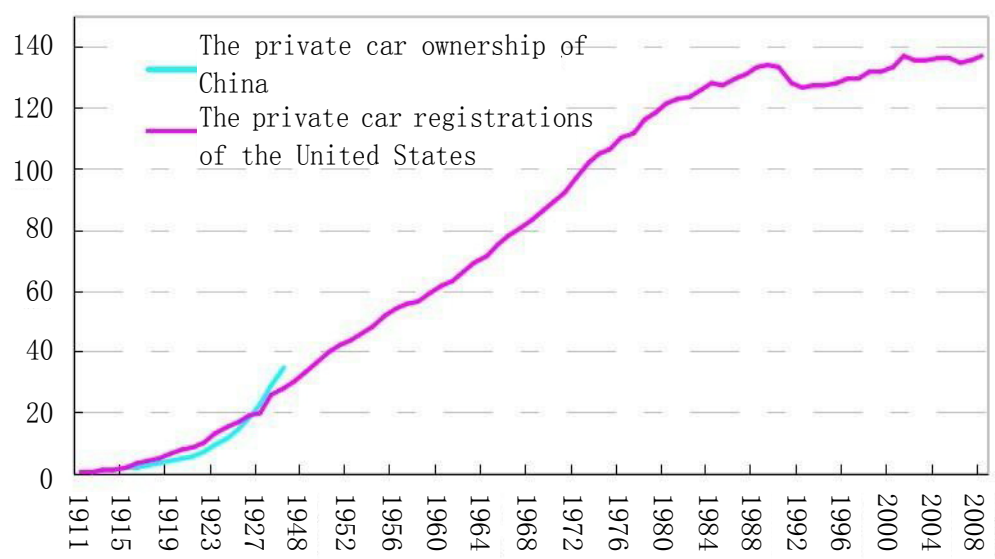

Figure 6. The amount of private cars in China and the amount of registered cars in USA Unit: million. China: 1990-2008, USA: 1911-1927, 1945-2008.

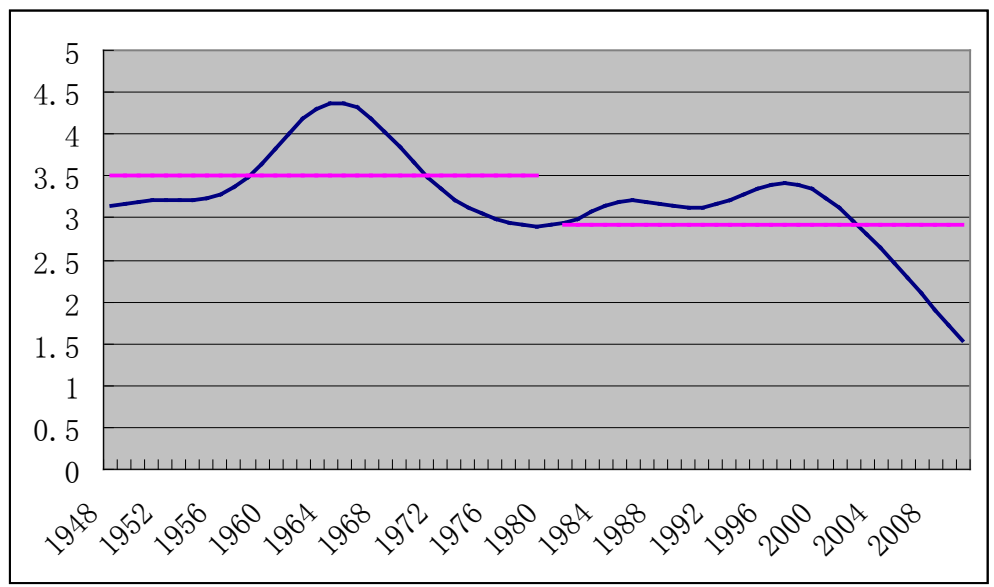

Figure 7. Increasing speed of USA GDP and its average value (1948-2010) Unit: \% (The value of GDP is obtained by means of H-P Wave Filering).

to $41 \%$, from $16 \%$ up to $30 \%$ in developing countries, and $11 \%$ up to only $19 \%$ in China. Thus, there is a large gap between the urban area and rural area. After 1978, the rural-urban gap collapsed with the quickening pace of urbanization, and with the annual increasing rate of $1 \%$. In 2011, the urbanizing rate came up to $51.27 \%$ if this speed is maintained, China will realize is urbanization in 2030 with its urbanizing rate past $70 \%$ (Figure 8).

Compared with USA, China has attended the stage of high-speed urbanization. It, however, is quite different from that of USA. With 1995 as a boundary line, the proportion of population of small/mid cities/towns shows a tendency of from contraction to expansion. How to understand the contraction? It gets involved a lot of Chinese specialty. Firstly, the multiplicity of investors and investing channels brought about by the reform and opening up campaign has promoted the quick development of enterprises at the town level, and, main while, it has made the small cities or towns expand quickly, and the rural people started their own urbanization on the very spot. Secondly, the varied city-layout criteria make the economy develop in diversity. In the early 1980s, China began to implement the municipality-over-county system, which made it possible for municipalities to mushroom thick and fast. In 1980s, China conducted a political policy of replacing communes with townships, which made the townships and county-level booming in great numbers. Thirdly, in 1990 when there was the fourth population census, China adopted the new population registering criteria, namely, the population is registered according to the regional aspect (according to the new criteria, a person can be registered as an urban inhabitant if he or she stay in certain city or town in more than six months).

In all, China's population contraction before 1995 is different from that of USA in that China's population contract does not a process of the shifted suburbanization, but the change of inhabiting place based on China's 


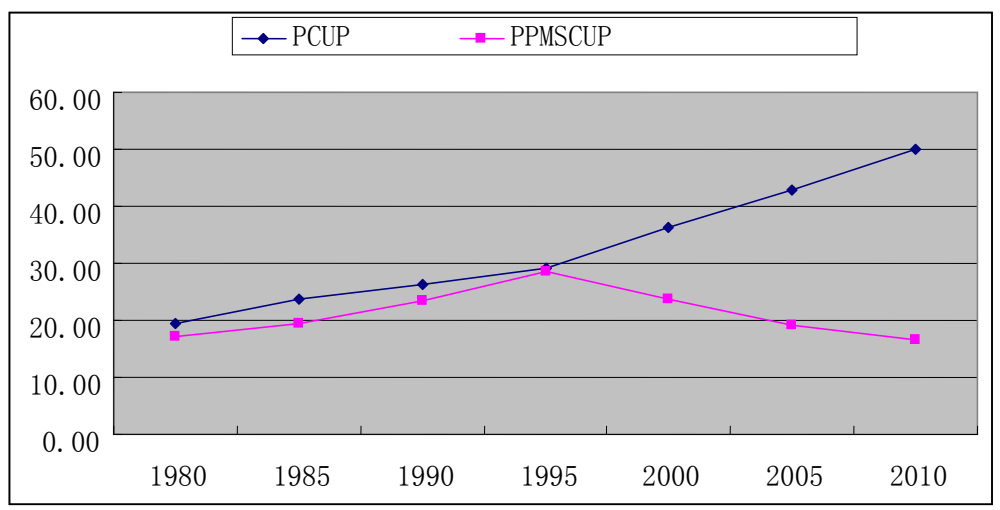

Figure 8. Proportion of China's urban population (PCUP) and proportion of population in mid/small-sized cities/towns in urban population (PPMSCUP) Unit: \%. (Note: the mid/small cities or towns mean a city or town with less than 500,000 of urban inhabitants). Data comes from Statistic Yearbook of China.

system, policy and statistics. It shows as "the on-the-spot urbanization". On the whole, China's urbanization nowadays equals to that of USA before 1920. The figure shows no sign of suburbanization.

\subsubsection{Geographic Distribution of China's Urbanization ${ }^{2}$}

The three Figures 9-11 reveal the geographic distributing feature of China's urbanization: 1) Seen from the eastern, middle and western sections of China, the urbanization in the west has been backward from the average level for a long time; the middle section has gradually developed from above the average level to below the average level; and the eastern section is above the average level all the way. This shows an expansion of geographic gap; 2) Seen from china's most developed three municipal sections, its urban population proportion is $25 \%$ of the total proportion of all China's population in 1980, and 34\% in 2010, which shows the shift of population toward the big cities; 3) Seen from the urban population proportion of the three big cities to the total population of the three cities, up to 2012, the Yangtze Delta municipal section and the Zhujiang Delta municipal section develop fast that Beijing-Tianjin-Hebei municipal section in that the urbanization data has passed $65 \%$. As far as the data are concerned, urbanization has been realized in the region. Generally speaking, China's urbanization greatly features in unbalance, with the geographic gap expanded further, and with no sign of contraction.

\subsubsection{Alteration of Industrial Structure during China's Urbanization}

After 1980s, China's fast urbanization has been accompanied with the booming development of manufactory industry and the population shift toward the advanced areas. On the one hand, China has become one of the acceptable zone for the global industrial shift, in other words, the traditional western manufactory industry has shifted from Japan and Germany to the newly established markets headed by China, which has formed China as a great power of manufactory industry. And on the other hand, the favorable policy of the coastal region of China results in the eastward concentration of productive elements, which makes expansion of the gap between the rural area and urban area. The industrial structure of this period shows consistent adjustment.

Firstly, the proportion of agricultural GDP has been declined continuously. In 1980 when the Chinese agriculture covers $22.8 \%$ of GDP, with the 2010 GDP of 5000 dollars, down to $5.4 \%$, which equals to the income of USA in 1970. Secondly, the manufactory industry is always developing at the rate of $30 \%$. In 2010, China surpassed USA as the largest country of manufactory industry (19.8\%:19.4\%). (Figure 12) Its developing advantages lie in the economic scale, resource investment, low cost, investment and globalization. Some advantages can not be replaced, which will maintain for a long period. Nowadays, the global manufactory industry has developing into the stage of innovation. Specifically speaking, it refers to the production of green food, the innovation of commercial mode, integrity of internet, the stability of customers, the swift production, and the service of manufactory industry, etc. There is a vast gap in this aspect, which leads to the big but weak situation of

\footnotetext{
${ }^{2}$ The data come from China Economic Database and Statistic Yearbook of China.
} 


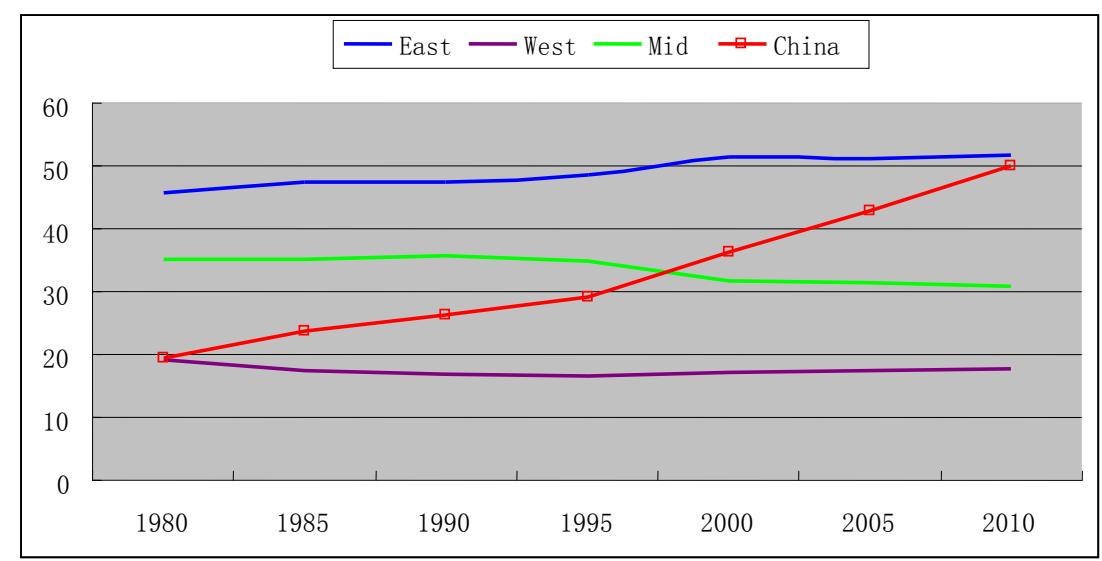

Figure 9. Proportion of population in various region of China Unit: \%.

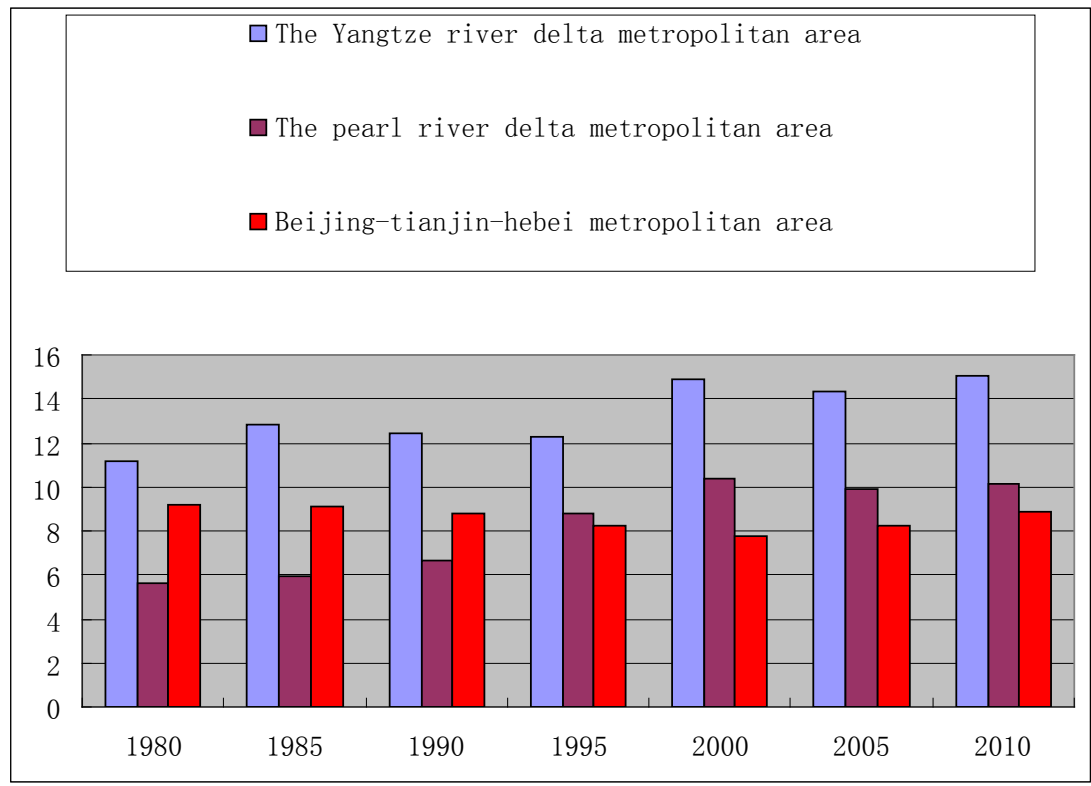

Figure 10. Population proportion of three-city circle in China’s population Unit: \%.

China's manufactory industry. Thirdly, the GDP of the service industry, financial and trade industry has maintained a rising tendency, which falls behind the USA. 1980 saw the GDP covering 8.9\%, 19.8 with its increasing speed of $110.0 \%$ and $147 \%$ with the total sum of $38.5 \%$. By comparison with the USA's inner structure of service industry, it can be seen that China's service industry is composed mainly of the traditional industries, such as the communication and transportation industry, preserving industry, post industry, mass sale and detailed sale industry, and housing and food industry, with its GDP value surpassed 40\%, occupying the dominating position. And the productive service industry, such as financial industry, insurance, information transportation, computer service and software, scientific research, and technological service, etc., possess a low standard, with a proportion of 20\%. Additionally, the building and transportation industry before 1995 maintained its trend of stable development, and, in the following years, a level of $11.5 \%$ or so was kept.

\subsubsection{Developing Situation of China's Automobile Industry ${ }^{3}$}

China's automobile industry is greatly influenced by the governmental policy. Before 2000, the automobile industry developed fairy slowly, while developed fast in the following years, so much so that the productive

\footnotetext{
${ }^{3}$ Data are from Statistic Yearbook of Industrial Economy of China, Yearbook of Mobile Industry of China, and the information internet of the
} Association of Mobile Industry: http://www.auto-stats.org.cn/default.asp 


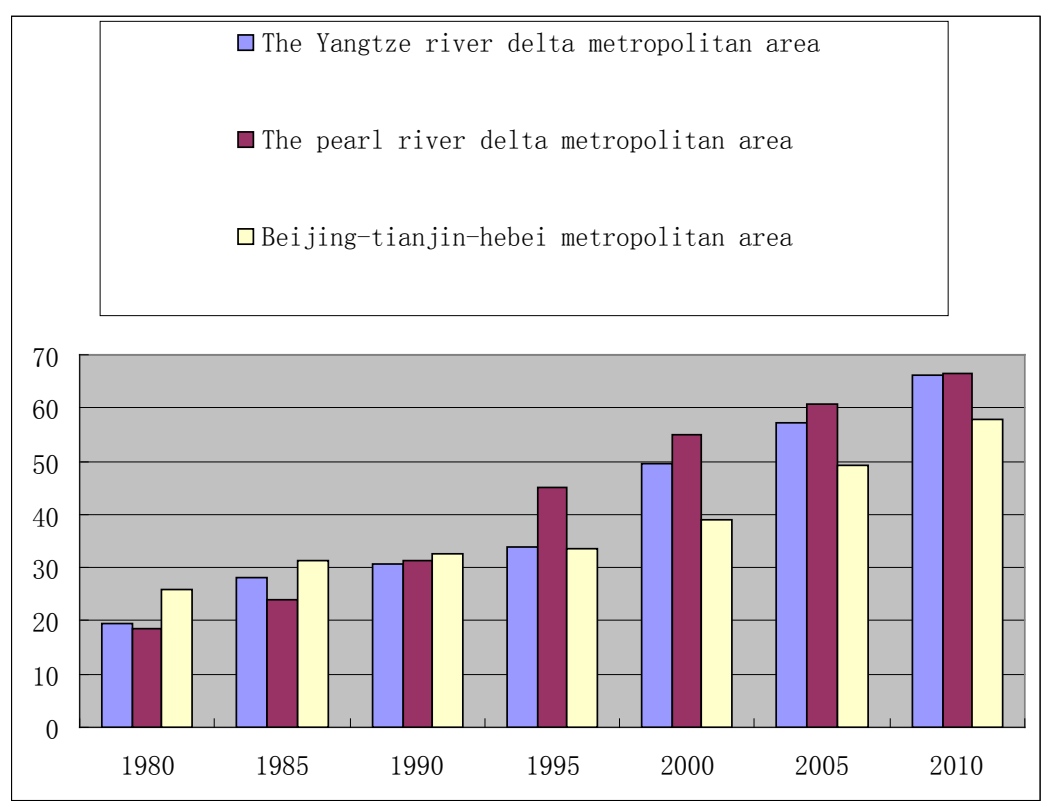

Figure 11. Proportion of urban population of the three cities in their total population Unit: \%.

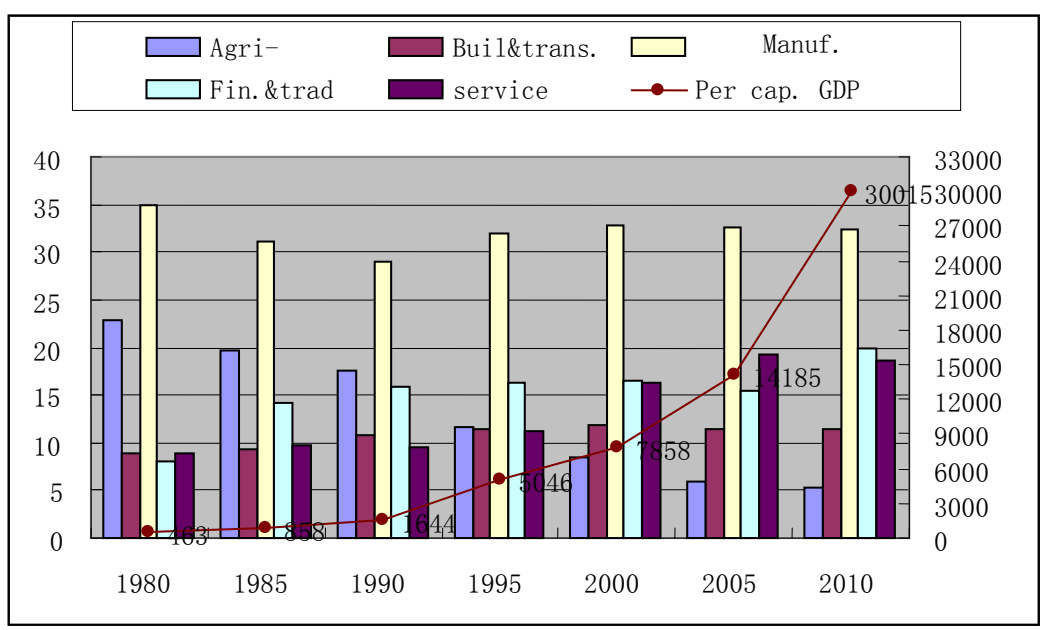

Figure 12. Alteration of GDP proportion in China's industries and per capita GDP (Left side unit: \%, right side unit: yuan). Data comes from China Economic Database.

amount came to $18,260,000$ cars in 2010 from the 2,070,000 cars in 2000, 23.5\% of the total production all over the world. In 2009 China surpassed Japan in car sale and became the first car-production country in the world. According to the sales report published by the Automobile Association in 2012, 19,271,800 cars were produced and 19,306,500 sold, up $4.63 \%$ and $4.33 \%$ of increase. Of the transporting cars, 15,523,700 cars produced, and 15,495,200 cars sold, up 7.17\% and 7.07\%; 3,748,100 business cars were produced and 3,811,200 cars sold, down $4.71 \%$ and $5.49 \%$. In 2012, China, for the fourth time, was list No. 1 in the world in production and sale of cars (Figure 13, Figure 14).

Along with China becoming the first country of production and sale of cars in the world, the automobile industry has become an important key industry in China's national economy. In 2010, China's automobile industry contributed $13 \%$ of China's taxation and $6.13 \%$ of GDP. Judged by the possessing amount of private cars in USA during urbanization, China's automobile market will probably the largest potential automobile market in the future. 


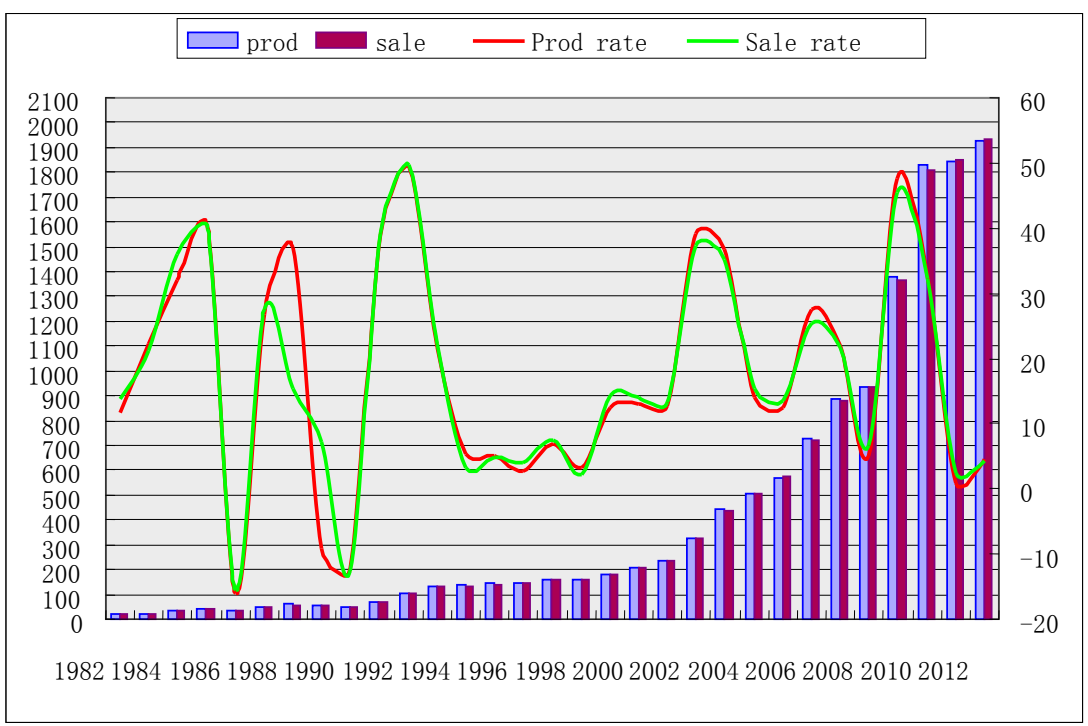

Figure 13. China's annual sale of automobile and its increasing rate (1982-2012) (Left side unit: ten thousand, right side unit: \%).

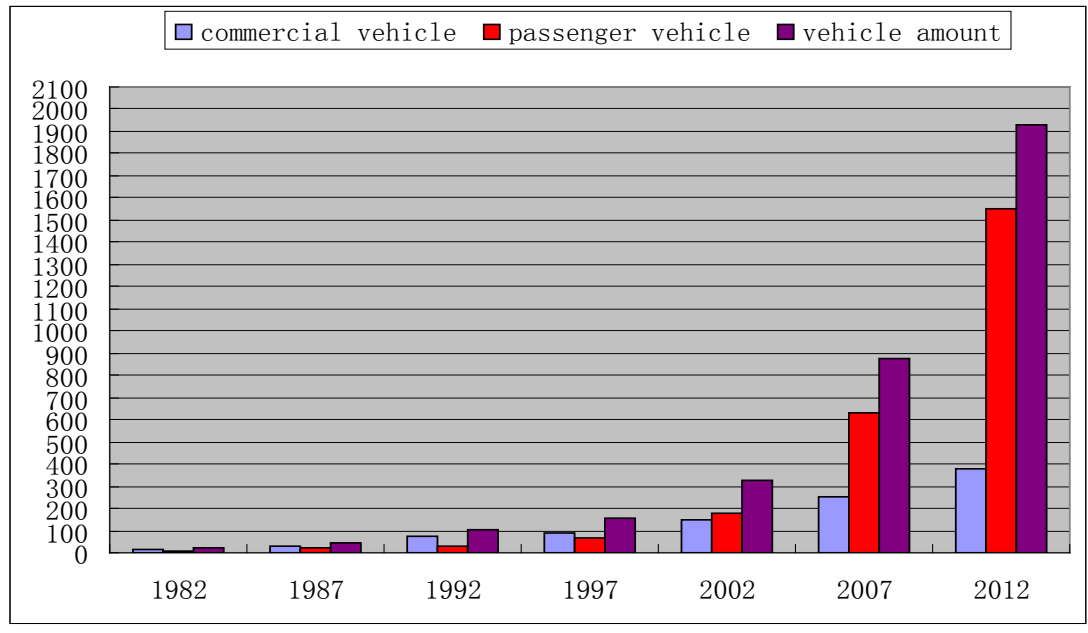

Figure 14. Alteration of China’s automobile industry structure Unit: 10,000.

\section{Conclusions and Revelation}

American urbanization, for certain, has a positive relationship with its economic development, though the relationship is not reasonable in all the other countries. Compared with the developed countries with $70 \%$ of urbanization, China, with about $50 \%$ of urbanization, has a long way to go. In the further urbanization, the positive relationship in American urbanization should be studied profoundly, and, by means of urbanizing promotion to economic development, mid-income trap will be effectively avoided.

Since 1920s up to now, American urbanization has kept developing along with suburbanization. Suburbanization realized the balanced development among various regions, and mean while, the development of suburban financial trade and service industry brought about the shift of American industrial structure. The American suburbanization results from the pursuit for the life quality by the rich and the suitable support by the governmental policy, which gives rise to a sound recycle of the move of mid-class-promotion of investment and consumers-more people on the shift.

Nowadays, China's population density is ten time than that of USA, which has brought about series of urban diseases. It is outstanding that China's regions develop in an unbalance manner. Thus, the urbanization in the future will depend on suburbanization and the development of mid-small towns and cities. At present, China's 
urbanization in mid/small towns or cities is by far backward than the whole urbanization. As far as the government is concerned, it lies in the fact that the government officials are favorable to the big cities, and that, in a long run, the governmental investment and policymaking become city-entered.

As far as the individual is concerned, the blind investment, the development of towns or townships, will bring about serious pollution to the environment of the mid/small towns or cities. Thus it lacks attractiveness to the rich who are apt to move to the mid/small towns or cities, nor can it promote investment and consumption. If there is no increase of inner requirement in urbanization, it, in the worsened condition of outer environment at present, will probably be caught in the condition of many developing countries, that is, urbanization has nothing to do with economic development. There is something more in it, which is deserved to be studied further.

In the course of American urbanization, the ratio of manufacturing was continually decreasing, but the quality of the products has been improving. After 1950s, the traditional factories of steel, chemical and textile were moved to countries oversea, but the automobile industry which needs higher technology was always rising in the United States. Up to 2012, the United States still produced and consumed the second most automobiles in the world. Moreover, this country also is most active in the innovation-driven patterns in the world. The area is quite advanced in the R\&D and the brand effect in automobiles, the market of accessories and maintenance (including gas and oil, insurances, accessories and spares, automobile finance, consumption credit and loan, reports of second-hand cars, discarding, recycling and dismantling). By contrast, the manufacturing in China is still in the process of factory model, which is the stage of investment expanding and scale enlarging. This model is limited in its profits. There are three deficits in the development of automobiles in China: deficit in innovation, deficit in complete chain of car industry, and deficit in brand effect. For a long time, the automobile industry in China has been trapped by "introducing-falling behind-re-introducing—falling behind again" (Huang, 2012). About 85\% of clutches and engines have been repeated imported and top 100 OEMs for accessories does not include any in China. No automobile company in China ranks top 10 in the world. The market of maintenance is very weak and poorly-managed. Considering the importance of automobiles, the alteration of industrial structure in automobiles is mostly probably the sign of China's advancement from "a big place" into "a strong place" of manufacturing.

\section{Further Research}

Why is urbanization positively related to economic growth in some countries and regions, but not directly related in some other countries and regions? This needs to be studies further. The new leaders in China have proposed that China should enhance economic growth through urbanization. Misunderstandings may probably occur if the international relationship between economic growth and urbanization is not clarified.

A comparative study of the urbanization of two cities, one in China and one in the United States, by constructing indexes and models of efficiency evaluation, may be an innovative point of study. This may also be good in guiding policy-making. In other words, a study of samples is very necessary in terms of the scale of industry and the importance of automobiles in industry in China.

\section{Funding}

Funded by National Humanities and Social Science Key Research Institute Fund Project of China (12\&ZD100); Chongqing Humanities and Social Science Research Institute Fund Project (2012YBJJ027); Fundamental Research Funds for the Central Universities (SWU1309368).

\section{References}

[1] Henderson, J.V. (2003) Urbanization and Economic Development. Annals of Economics and Finance, 4, 275-341.

[2] Gustan, R. and John, C.H.F. (1961) A Theory of Economic Development. American Economic Review, 51, 533-565.

[3] Jorgenson, D.W. (1969) The Development of a Dual Economy. The Economic Journal, 59, 147.

[4] Michael, P.T. (1969) A Model of Labor Migration and Urban Unemployment in Less Developed Countries. American Economic Review, 59, 147.

[5] Rostow, W.W. (1971) The Stages of Economic Growth. Cambridge University Press, Cambridge.

[6] Chenery, H.B. and Syrquin, M. (1975) Patterns of Development, 1950-1970. Oxford University Press, New York.

[7] Syrquin and Chener (1989) Three Decades of Industrialization. The World Bank Economic Reviews, 3, 152-153. 
[8] Song, J.P. and Li, X.Q. (2006) Insights in American Urbanization for China. Issues in Cities, 1, 88-92.

[9] Wang, C.Y. (2007) History and Features of Urbanization in the United States and Its Inspirations. Issues in Cities, 6, 92-98.

[10] Wang, H. and Jiang, C. (2010) Experiences of Industry Growth from American Urbanization. Report by Guotai Junan Securities, Oct. 11. 
Scientific Research Publishing (SCIRP) is one of the largest Open Access journal publishers. It is currently publishing more than 200 open access, online, peer-reviewed journals covering a wide range of academic disciplines. SCIRP serves the worldwide academic communities and contributes to the progress and application of science with its publication.

Other selected journals from SCIRP are listed as below. Submit your manuscript to us via either submit@scirp.org or Online Submission Portal.
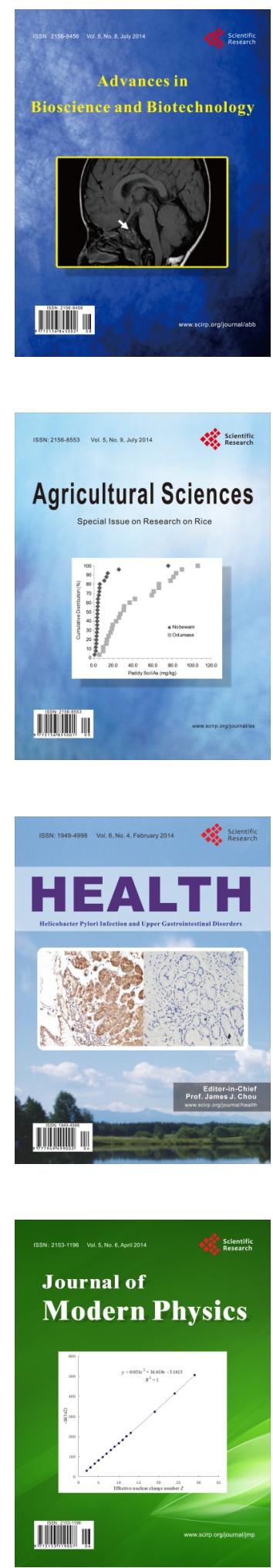
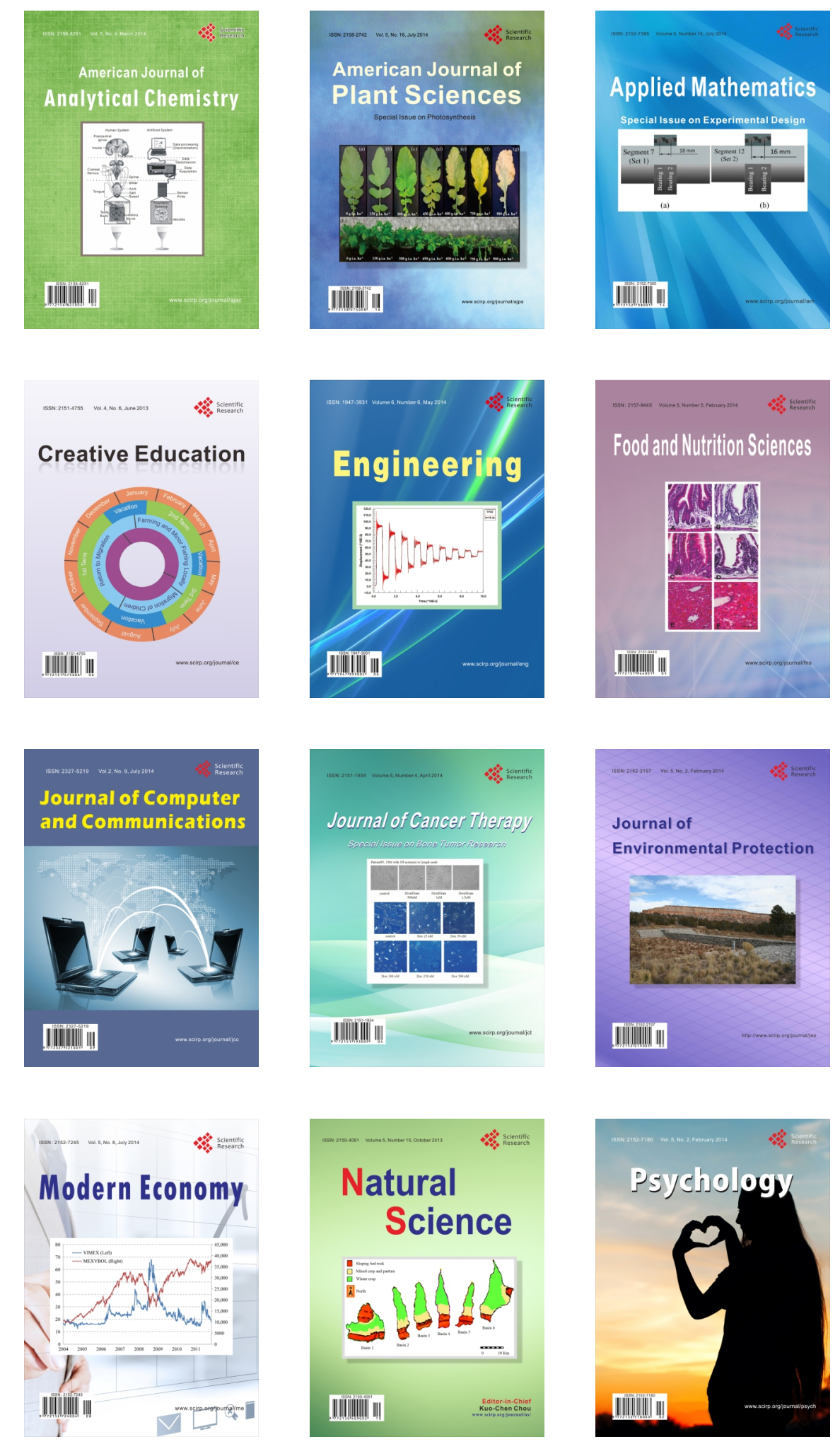